\title{
China in Afghanistan: Contemporary Engagements and Challenges Ahead
}

\author{
Muhammad Daim Fazil \\ The writer is associated with State-Run TV Channel
}

\begin{abstract}
Recent interpretation on China's attitude toward Afghanistan has discussed that it is either motivated by opportunistic free ride on US-NATO sweats or a fundamental caution driven by security apprehensions in its restless province of Xinjiang. This paper argues that China has three principal objectives embedded with Afghanistan: (1) to safeguard the security of Xinjiang; (2) to shelter the expansion of greater economic contacts, with investment in natural resources; and (3) to battle the impact of the United States, West and of India. The paper also illustrates the current Chinese engagement in Afghanistan and future challenges it might have in presence of U.S., the Western and regional competitors.
\end{abstract}

\section{Introduction:}

International community is witnessing remarkable Chinese rise for more than last two decades. China's astonishing economic performance, its strategy to deal with internal and border disputes and doctrine of peaceful emergence has made it probably much more valuable in the global standing than any other country of the world. Continuous growth of economy (at almost 9 percent annually), large scale overseas socio-economic initiatives and extensive contribution in international organizations amplified Chinese regional and global stature. Beijing's contribution and special assistance to underdeveloped or developing countries has increased its stakes. Though many view Chinese activities in third world countries with narrow angle however, the state which is receiving millions of financial aid, concessionary loans and extensive foreign direct investment, has welcomed any sort of Chinese undertakings in its country trusting that every Chinese Yuan would put the feeble economy on the right path and thus become a reason to accelerate the lifestyle of a common man. China's overseas activities are not merely restrained to one region or for one specific goal; rather the activities are seen across the globe with wide range of objectives. Not unsurprisingly, China has taken every prospect to benefit from the vacuity in Afghanistan for economic prospects. It has fortified rights for copper mining and has been looking for opportunities to assume other mining projects. It has also invested in rail and road networks in those portions of Afghanistan in which China has an interest.

\section{An overview to Sino-Afghan relations:}

In retrospect, China and Afghanistan had friendly proximities largely because of commonalities in culture, linguistic characters and the existence of Buddhism and Islam in both the countries. However, with the advent of modern era in 21st century the relationship witnessed some ups and downs. Afghanistan was among first few which admitted the birth of Communist China and initially showed tremendous esteem in the developing relations between the two. However, due to Kabul's penchant towards USSR in 1950s, China remained reluctant to come to establish full diplomatic relations with Afghanistan up till 1955. China's friendly relations with Afghanistan were largely determined by two major events i.e. the Sino-Indian border disagreement which remained unresolved despite Chinese Premier Chu En Lai and his Indian counterpart Nehru's meetings in this regard--- and secondly the Sino-Soviet split on the border talks. ${ }^{1}$ China and Afghanistan signed "Friendship and Mutual Non-Aggression Agreement" in $1960 .{ }^{2}$ China didn't favor Soviet invasion of 1979 and tried to resolve the issue peacefully. At that time, Beijing also favored Afghani stand regarding Soviet infiltration. After Soviet collapse, the Pashtun-dominated Taliban came to power in 1996 in the middle of the chaos that had made inroads all over the country since the beginning of the Afghan Civil War. However, this time Beijing didn't show satisfaction and favored global stance on Taliban. The Sino-Afghan engagement remained frosty during that period. America was quick to respond after September 2001 attacks in its vital cities and plunged in Afghanistan with an aim to root out terrorism once for all. The catastrophic event was not only condemned by China but PRC backed US led ISAF initiative to wipe out Taliban and terrorist sanctuaries in Afghanistan alike.China, though, played no part in this alliance, for two reasons. First, it desired to stick around its long-lasting policy of not involving itself in any military engagement abroad. Second, it sought to wait for

${ }^{1}$ Jonathan Z. Ludwig, Sixty years of Sino-Afghan Relations, Cambridge Review of International Affairs, Vol. 26, No. 2, 2013 , p. 397.

${ }^{2}$ Shen-Yu Dai, China and Afghanistan, The China Quarterly, No. 25 (Jan - Mar, 1966), p. 213. 
the final conclusion, to define who would become the new authority in Afghanistan, and there fore make sure it would not have offended the winning side. China never amalgamated in the multinational forces active in Afghanistan. It didn't allow NATO/ISAF forces to maneuver their operations by using Chinese bases or airspace. $^{3}$

Despite providing enough moral and political support, China felt its stakes in jeopardy once US led ISAF forces entered Afghanistan. Its been decade since US and ISAF forces are in Afghanistan but no vivid projection of Afghanistan is still available. China is taking keen interest in volatile and destructive state of affairs of Afghanistan.

\section{Chinese assistance to Kabul in different fields after 9/11:}

China has been taking generous undertakings in the socio-economically feeble Afghanistan especially after 9/11. Beijing provided all sorts of construction assistance and also participating in the development of structure as well. ZTE and Huawei, the two Chinese companies, worked together to improve the telecommunication network which comprise of 2000,000 lines. This was the first project in which China was involved after 9/11. European Union also hired several Chinese companies for reconstructing roadsand hospitals in Kandahar and Kabul. PRC contributed in the Parwan irrigation project and construction of dam in this region. ${ }^{4}$ China Metallurgical Company won exclusive rights for Aynak Copper field for 30 years from which Afghanistan to get US\$ 400 million per annum in the shape of tax. ${ }^{5}$ Winning this bid by overcoming and circumventing rich Western and American companies was indeed a muscular move. China had been looking for deals of this kind for years and therefore getting Aynak Copper field rights is not a big surprise.

Table: Chinese Economic Assistance to Afghanistan

\begin{tabular}{|l|l|}
\hline Year & Aid (\$millions) \\
\hline 1964 & 28.5 \\
\hline 1972 & 44 \\
\hline 2001 & 4.0 \\
\hline 2002 & 150 \\
\hline 2009 & 75 \\
\hline Total & 301.5 \\
\hline
\end{tabular}

Source: Created by author

China's support to Kabul in security matters also enhanced after 2001. Once the new Afghan administration under President Hamid Karzai was installed, Mr. Karzai tried to upgrade the Afghan National Army (ANA). And it was after high level of Chinese officials visits to Kabul that Beijing reconfirmed its defence and security pledge to Afghanistan. Weapons worth US $\$ 2$ million ${ }^{6}$ were provided to Kabul by China and a training program for Afghan Defence Ministry officials was also initiated. China and Afghanistan also concluded a Memorandum of Understanding (MoU) other than Chinese additional commitment to train30,000 ANA soldiers. ${ }^{7}$

China's political commitment with Afghanistan has also enlarged in contemporary years, predominantly through the forum of the SCO. Currently Afghanistan is not a member of the SCO but it has nevertheless been a state of real concern to the organization's core stakeholders, China and Russia. The organization has recognized the immediate and long-term impact of stability in Afghanistan. The SCO shares three mutual interests with U.S/NATO i.e. combating terrorism, extremism and separatism ${ }^{8}$ altogether and to contain the re-emergence of Taliban. However, the organization's vision entitled with "Shanghai Spirit," founded on the pledge to non-interference in the inner matters of member states, has restricted its capability to vigorously contribute to this objective. While this has disallowed any of its members independently from promising military personnel to the US-NATO effort, it has focused on supporting problems such as providing military/police training for Afghan security forces and counter-terrorism and military equipment. The SCO states' own apprehensions with the probable spill-over of Afghan volatility into their states-specifically the drug trafficking, organized crime and militant Islamism - has evidently been the central driver of such actions. The likely relationships between the opium trade and terrorist groups have been of specific anxiety for Beijing due to the upsurge in circulation of the narcotic into Xinjiang in the last decade. ${ }^{9}$ The SCO has realized that

\footnotetext{
${ }^{3}$ Jonathan Z. Ludwig, Ibid. p. 402.

${ }^{4}$ Ibid.p. 403.

${ }^{5}$ Ibid.p. 405

${ }^{6}$ Vishal Chandra, Making of the New Afghan National Army: Challenges and Prospects, Strategic Analysis, Vol. 33, No. 1, January 2009 , p. 63.

${ }^{7}$ Ibid.

${ }^{8}$ Michael Clarke, China's Strategy in “Greater Central Asia: Is Afghanistan the Missing Link?',Asian Affairs: An American Review, Vol. 40 , No. 1, (2013), p.14.

9YuliaKudriashova, “The Afghan Crisis and the Shanghai Cooperation Organization,” New Eastern Outlook, July 25, 2011, p. 59.
} 
continuing unrest in Afghanistan is a hurdle not only in the economic comfort of Afghanistan but also a hindrance and possible intimidation to their investments there.

\section{Security threats and spillover effects:}

\section{Challenges:}

China has every reason to back up the stability and security of its neighbors. It shares a mutual interest with the West and U.S. in averting the region from turning into a ground for terrorists. ${ }^{10}$ A stable security setting for Xinjiang, the agitated province that is hub of China's major Muslim group, the Uighurs, is of abundant significance to Beijing. Since 1990, China is facing the unprecedented challenge of Uighurs activities in Xinjiang. Turkish speaking Uighurs community has cultural links with Central Asia as well and they have economic resentment against government. ${ }^{11}$ This arrogance resulted in the development of Uighurs militants and their linkages in Afghanistan, troubled areas of Pakistan and of CARs. Apart from the direct danger of crossborder drifts of militants, arms and narcotics, the ideological impact of pan-Islamic jihadi factions has played a central role for Uighur pro-independence groups. ${ }^{12}$ China has been the target of assaults from radicals trained in Afghanistan, and it is assumed that some Uighur militants are still based in either FATA area of Pakistan or in the eastern and southern provinces of Afghanistan. ${ }^{13}$ While several of these militants are associated with other transnational radical groups, like the Islamic Movement of Uzbekistan, slight numbers are still supposed to be active within those groups that target China specially, such as the East Turkestan Islamic Movement (ETIM) or Turkestan Islamic Party (TIP), which look for to create an Islamic state of East Turkestan in Xinjiang. In spite of the fact that Xinjiang is severely troubled by the turbulence of Afghanistan and Taliban plus other militant assemblage created mess in the Chinese province, Beijing has not taken matters in its hand entirely. Taliban government further strengthened the position of culprits as because of Taliban in command, they had no real danger of residing in Afghanistan. Similarly after U.S. attack on Afghanistan, the threats of drug trafficking, arms movement and narcotics supply also increased in Xinjiang ${ }^{14}$ and in the entire region. But China didn't opt the way like U.S. did. China tried to exert the pressure on the dissidents through Afghan government and via other channels rather going directly into the matter. It is because China feels that sending its troops to root out radicals may bring China on the front row of militant's targets. Therefore, China absorbed the consequences of human causalities and other damages but did not alter his historic stance of sending troops for safeguarding its stakes.

Despite good ties with current Afghan government and pouring millions of dollars in Afghanistan, it has not been easy going for China. Chinese initiatives to reconstruct and to renovate the dire structure have experienced severe pressure and threat of militant attacks. First such experience resulted in several causalities of its engineers working in Kandoz province. ${ }^{15}$ The victims were of China's Shisigu Railway Group and were basically hired for completion of road projects. China responded harshly and demanded Afghan Government and United Nations also to investigate the issue and to bring the culprits into account. ${ }^{16}$ However, the attackers could not be found so far. Another incident of the kidnapping occurred in 2010 when gunmen kidnapped two Chinese engineers in Fayrab province. ${ }^{17}$ Other than these incidents, Aynak copper field also came under rocket attack by some unknown men.

\section{The Western challenge:}

As the US prepares to scale back its military presence in Afghanistan this year, China has begun to contemplate a geopolitical "march westwards". Beijing hopes to trigger an economic boom in its restive western Xinjiang province by re-vitalizing the ancient Silk Road, which runs through its Central and South Asian neighbors. Beijing has largely taken a low-profile and cautious approach toward the conflict in neighboring Afghanistan since the overthrow of the Taliban in 2001. But there is growing concern among the Chinese leadership that NATO could leave behind a security vacuum in Afghanistan, which would potentially jeopardize China's economic investments in the broader region. The long stretched Chinese projects in Afghanistan remained vulnerable not only to local warlords and to Taliban or other militants, but Chinese have the sway of Western and American companies, though not in terms of killing or harassment of its engineers but in the shape

\footnotetext{
${ }^{10} \mathrm{~J}$. Todd Reed and Diana Raschke, The ETIM: China's Islamic Militants and the Global Terrorist Threat(London: PRAEGER Publications), 2010), p. 106.

${ }^{11}$ Keshav Mishra, "China's Response to 11 September", Strategic Analysis, Vol. 25, No. 9, December 2001, p. 1075.

${ }^{12}$ MuradBatal al-Shishani, “Journal of the Turkistan Islamic Party Urges Jihad in China," Terrorism Monitor, Vol. 7, No. 9, April 10, 2009), p. 54

${ }^{13}$ Ibid. p. 55.

${ }^{14}$ Syed WaqasHaiderBukhari, "The Role of China in Economic Stabilization and Reconstruction of Afghanistan", Margalla Papers, Vol. 16, Issue No.1, 2012, p 40.

${ }^{15}$ Jonathan Z.Ludwig, Op Cit. p. 403.

${ }^{16} \mathrm{http} / / / \mathrm{www}$. theguardian.com/world/2004/jun/10/afghanistan.china (Accessed on 10 May 11, 2014)

17،"Taliban Kidnap Two Chinese Engineers, Four Afghans," Associated http://www.google.com/hostednews/afp/article/ALeqM5jGr744c2ihCH1 Uu PJqvBmH7RmmoQ.

Press, January $17, \quad 2010$, 
of getting more public sympathies and larger share from the huge natural resources of Afghan land.China's geopolitical observations are also considerably dissimilar from those of the United States. China considers U.S. role in the region as problematic in two ways; one because of the U.S. presence which China perceives as a strategic threat and secondly the agitation that is generated in the last decade, ${ }^{18}$ largely because of U.S. forces stay and operating procedure in Afghanistan. Many Chinese consider that the United States is not only driven by counterterrorism actions--if at all--but has also, and largely, a geopolitical goal: to wield control and authority over the regional energy routes and "encircling" China. ${ }^{19}$ The result of China's geopolitical observations is profoundly fluctuating about U.S. accomplishment in Afghanistan--unless accomplishment means withdrawal. China has no motive to see a hasty withdrawal, but would surely desire a limited U.S. presence. While it does not desire to see a success for the radicals, and definitely would not deliver them any support. Beijing remains intensely skeptical about NATO's long-term purposes in Afghanistan. China perceives NATO and the United States as transformational players ${ }^{20}$ in Afghanistan, something abhorrence to China's regional and global framework. Moreover, the prospect of extended military roots in Afghanistan and Central Asia, along with the expansion of nations molding themselves on American-style democracy or leadership's affiliation with Washington, is distressing to Chinese planners. The volatility that resulted in Colour Revolutions in Georgia, Ukraine and Kyrgyzstan has made China more skeptical towards Western democracy. ${ }^{21}$

\section{The Indian challenge:}

India's regional dominance in South Asia, its friendly ties with Hamid Karzai and historic affiliation with Northern Alliance make her a major stake holder in Afghanistan, despite the fact that it shares no boundary or direct link with Afghanistan. Together with fears of encirclement by West, China also fears of increasing Indian influence in Afghanistan. Other than pouring economic assistance, more than US\$ 2 billion, ${ }^{22}$ India has been giving defence and military help to Afghanistan. In a recently concluded 'strategic Deal' with Afghanistan, India to will train $\mathrm{ANA}^{23}$ and facilitate it with sophisticated weapons. Kabul-New Delhi ties are mounting since the ouster of Taliban regime in 2001 and have come to closer partnerships in several fields. Any Indian endeavor to safeguard its interest inside Afghanistan will put Chinese stakes in jeopardy. Moreover, recent IndoUS Nuclear deal has put China on the defensive side. It is New Delhi's prudently crafted policy that it has warm relationship with the United States, which want to see India as a watchdog in post 2014 scenario and a regional challenger to Beijing's emergent influence, with Russia, who has somewhat mutual interest in the region and lastly India is having pleasant connections with subsequent Afghan governments after 9/11. The Indian challenge may not be as severe as the West but calculating all these challenges will ultimately result in the encirclement off China. Therefore, China and Pakistan are trying to alter their mechanism of dealing Kabul with additional usage of economic tools and public diplomacy.

\section{The Pakistan challenge:}

There are also several contradictions in China's approach toward Afghanistan. The utmost of them is Beijing's "all weather" corporation with Pakistan. While China has consistently backed up Pakistan against pressures from India and U.S., principally on the foundations of strategic considerations, the comforts of Islamabad and Beijing in Afghanistan diverge as much as they converge. ${ }^{24} \mathrm{~A}$ stable government in Afghanistan and peaceful Pakistan goes largely in favor of China. Though Pakistan and China has always been on the course of cooperation historically, contemporary regional trends and internal happenings in both the countries demand modification in policies. Fresh ethnic and religious riots in Chinese territory were believed to be planned in Pakistan and the executors of these activities were trained either in troubled belt of Pakistan or in Afghanistan. ${ }^{25}$ China demanded Pakistan to take some serious and stern initiatives to stop the flux of radicals in China and also to offset their hideouts in Pakistan. On its part Pakistan has been uttering that it has taken all necessary steps to dismantle dissidents and their networks from its territory. Recently launched Operation ZarbE-Azab is also aimed at crushing terrorists and terrorism alike. On the one hand, China does not desire to see the US-NATO existence embedded so near to its delicate western boundary, but on the other hand it expects iron hand of U.S-NATO alliance against the Taliban, considering it very helpful for the safety of Xinjiang. It fears that any swift departure of US-NATO armies would not merely result in the return of instability but would also endanger its huge investments in Afghanistan and possibly make the state a sanctuary for Uyghur Islamists. ${ }^{26}$

\footnotetext{
${ }^{18}$ Andrew Small, China's Caution on Afghanistan-Pakistan, The Washington Quarterly, Vol. 33, No. 3, July, 2010 , p. 88.

${ }^{19}$ Ibid.

${ }^{20}$ RaffaelloPantucci, “China's Afghan Dilemma”, Survival: Global Politics and Strategy, Vol. 52, No. 4, August-September 2010 , p. 25.

${ }^{21}$ Ibid.

22 "India's Role in Afghanistan", Strategic Comments, Vol. 12, Issue 5, June 2006, p. 1.

${ }^{23}$ Khalid Ahmad, "Hopelessly Pavlovian Over Indo-Afghan Accord", Friday Times, Vol. XXIII, No. 35 (October 14-20, 2011$)$, p. 56.

${ }^{24}$ Harsh V. Pant, "India in Afghanistan: A Test Case for a Rising Power," Contemporary South Asia, Vol. 18, No. 2 (2010), p. 139.

${ }^{25}$ http://zameer36.com/the-bleak-side-of-sino-pak-relations/

${ }^{26}$ Michael Clarke, Op Cit, p. 15.
} 


\section{Beijing and Washington: So near so far:}

Robert D. Kaplan has argued that the efforts of the United States and NATO in Afghanistan are actually opening a door of opportunity for the strategic motivations of China in this vital region. ${ }^{27}$ Analysts on China also indicated that Beijing has been constantly divergent to US and NATO initiatives to widen China's rendezvous in the stabilization of Afghanistan. Such disagreement has involved Chinese denial to allow the United States to transport materiel and supplies to NATO forces in Afghanistan using its Wakhan passage as a substitute to supply logistics bypassing Pakistan route. These matters have led to notion that Beijing is modestly 'free-riding' on U.S. and NATO's expenses of "blood and treasure" in Afghanistan to secure advance entrance to that country's somewhat unexploited mineral resources.$^{28}$ However, some other observers have recommended that Sino-US benefits actually converge in Afghanistan and that these communal interests deliver the foundations for better teamwork with respect to Afghanistan. Believers of this opinion note that Beijing, because of its Xinjiang challenge, not merely shares Washington's interests in fighting Islamic radicalism in Afghanistan but also the objective of fortifying the formation of a steady and self-governing Afghan regime. From this viewpoint, then, Beijing's ostensible discretion in giving larger support to the United States and NATO exertions in Afghanistan originates from the circumstance that it observes Afghanistan completely through the prism of its Xinjiang dilemma. ${ }^{29}$ The Sino-US confrontation in the South China Sea over the Senkaku/Diaoyu islands and China is also seeking common ground with Russia, because it is aware that the US is a distant foe. According to recent reports, US officials trust that Beijing and Washington are fundamentally on the same page when it comes to battling Islamist militancy in Afghanistan, opening the likelihood of larger collaboration between the world's two most powerful nations. Despite its interest in fighting violence in Afghanistan, Beijing remains suspicious of a long-term American and NATO military existence in the region. The scenario and Chinese anxiety is described by Pakistani senator Mushahid Hussain Syed. He said "China is aware that there are certain lobbies, there are certain constituencies, there's a certain school of thought in capitals like Washington, D.C. or Brussels which talk of a China threat, which talk of containment of China, which talk of encirclement of China. Therefore China doesn't want that Afghanistan should become the center of a revived new great game that could in turn suck China into a debilitating tug of war strategically with the US or its proxies. ${ }^{130}$ Keeping in view the scenarios, it is understandable that both China and the United States are still unable to trust each other completely. Communal interests compel both the states to talk and share however, interests of each side have kept them involved in sidelined or covert activities so as to enhance the current and future role in Afghanistan.

\section{Conclusion}

Over the past six decades, the Sino-Afghan connection has reflected Chinese foreign relationships in other areas of the world. What commenced as a relationship intended to grant recognition to the new Communist system developed into a geopolitical scuffle against the Soviet Union subsequent to the Sino-Soviet split in 1960. This meant that China was at times unintentionally joined with the US, a coalition that nurtured nearer after the Soviet incursion of Afghanistan. After the Soviets departure, civil war in Afghanistan and the rise of the Taliban, the Sino-Afghan association began to be built on internal Chinese aspects and entered its most contentious phase. The contemporary relationship also has the aptitude to become controversial, particularly in light of similar Chinese actions across the globe in unsteady regions and with unpleasant regimes. What should be theoretically worrying to the PRC regime about the present state of the Sino-Afghan connection is how China is being supposed in other areas of the globe in which it is performing in almost similar fashion. The antipathy the Chinese are facing at how they are working in Africa and Central Asian Republics begs the demand of how long their distinctly one-sided natural resource- gathering pursuit will be endured within Afghanistan and what will be the complications when it starts to unravel.

China, which has been quite blunt and infuriated about its behavior under colonialism, is itself treating African and Central Asian states in much the same way that China itself was treated: as resource-producing colonies. While it is still difficult to dismiss the Sino-Afghan relationship in those terms, especially since China is not as deeply entrenched in Afghanistan as it is elsewhere, since China has been involved in infrastructure projects and since a number of other countries are also involved in Afghanistan, China's growing negative perception in other parts of the world should serve as a warning as this relationship continues to evolve.

Another fact making it difficult to discern the ultimate fate of the Sino-Afghan relationship, and what makes it particularly interesting to watch as it develops, is that this relationship differs somewhat from those China shares with its SCO neighbors and with various African nations. In the case of the African nations, China is interested

\footnotetext{
${ }^{27}$ Robert D. Kaplan, “Beijing's Afghan Gamble," New York Times, October 7, 2009, http://www. nytimes.com/2009/10/07/opinion/07kaplan.html

${ }^{28}$ Michael Clarke, Op Cit, p. 2.

${ }^{29}$ Andrew Small, “China's Caution on Afghanistan-Pakistan," Washington Quarterly, Vol. 33, No. 3 (2010), p. 87.

${ }^{30} \mathrm{http} / / /$ www.dw.de/china-seeks-strategic-advantage-in-afghanistan/a-17537791
} 
solely in gaining natural resources; it has no regard for the internal stability of individual African nations beyond ensuring that its workers are safe. With its SCO neighbors, it is also interested in gaining access to natural resources and has a growing presence in each. Though it is concerned about issues of stability in those countries, it generally has faith in the national governments of the SCO nations to deal with them alone or with Russian help. With Afghanistan, however, the situation is different. China has no large presence in the country yet, although it has economic interests, but it has no faith that the Afghan government, operating and policing itself, will be able to keep the country stable. The question of how China will react if and when the situation deteriorates to a point where Chinese interests, including Chinese border security and ethnic issues, are endangered makes the Sino-Afghan relationship different and important.

On a larger geopolitical level, a potential danger to Sino-US relations also arises from Afghanistan. Henry Kissinger, while recently discussing his book On China, noted that the politically initiated withdrawal of US troops from Afghanistan in 2014 could present a serious danger, for neither the US nor China will be sure any longer what the other is doing there; special forces operations and covert aid would obviously not be undertaken with the openness with which NATO/ISAF-Afghanistan operates and which currently limits Chinese opportunities for such operations. Thus, it is important that as Sino-US relations continue to evolve on all levels, some level of cooperation returns to their relationship within Afghanistan to avoid misunderstandings that could have greater international ramifications. 